Texas A\&M University- San Antonio

Digital Commons@ Texas A\&M University-San Antonio

History Faculty Publications

College of Arts and Sciences

1997

\title{
Parasites, Porotic Hyperostosis, and the Implications of Changing Perspectives
}

T. D. Holland

Michael J. O'Brien

Texas AઐM University-San Antonio, Mike.Obrien@tamusa.edu

Follow this and additional works at: https://digitalcommons.tamusa.edu/hist_faculty

Part of the Anthropology Commons

\section{Repository Citation}

Holland, T. D. and O'Brien, Michael J., "Parasites, Porotic Hyperostosis, and the Implications of Changing Perspectives" (1997).

History Faculty Publications. 18.

https://digitalcommons.tamusa.edu/hist_faculty/18

This Article is brought to you for free and open access by the College of Arts and Sciences at Digital Commons @ Texas A\&M University- San Antonio. It has been accepted for inclusion in History Faculty Publications by an authorized administrator of Digital Commons @ Texas A\&M University- San Antonio. For more information, please contact deirdre.mcdonald@tamusa.edu. 


\title{
ARTICLES
}

\section{PARASITES, POROTIC HYPEROSTOSIS, AND THE IMPLICATIONS OF CHANGING PERSPECTIVES}

\author{
Thomas D. Holland and Michael J. O’Brien
}

\begin{abstract}
Cribra orbitalia and porotic hyperostosis traditionally have been viewed (at least by archaeologists) as indicators of chronic iron deficiency anemia resulting from a dependency upon maize. Recent interpretations, however, have sought to explain these conditions as an evolutionary, adaptive response to intestinal parasites rather than as a consequence of poor nutrition. Thus diet is eliminated as a contributing factor. This model, however, adopts too simplistic a view of evolution. Furthermore, it concomitantly severs the well-documented link that exists between cranial lesions and cereal-based subsistence. A more realistic approach would be to incorporate both diet and pathogens (bacterial as well as parasitic) into a symbiotic model that acknowledges the important role of parasites in the etiology of cribra orbitalia and porotic hyperostosis, while maintaining the diagnostic value of these conditions as hallmarks of early agriculture.
\end{abstract}

Cribra orbitalia y porotic hyperostosis se han visto tradicionalmente (por lo menos por arqueólogos) como indicadores de anemia por deficiencia de hierro a consecuencia de una dependencia de maize. Interpretaciones recientes, sin embargo, han intentado explicar estas condiciones como una reacción evolutiva y adaptiva a parásitos intestinales en vez de una consecuencia de pobre nutrición. Entonces, la dieta es eliminada como un elemento contributivo. El problema es que este modelo adopta una perspectiva demasiada sencilla de evolución. Además, el modelo rompe el esclabón bien documentado que existe entre lesiones craneales y una subsistencia basada en cereales. Una aproximación más realística sería incorporar dieta y patógenos (los bacterianos tanto como los parasíticos) a un modelo simbiótico que reconozca el papel importante de parásitos en la etiología de cribra orbitalia y porotic hyperostosis mientras mantenga el valor diagnóstico de estas condiciones como señales de la agricultura antigua.

$\mathrm{I}$

n 1979 Gould and Lewontin attacked what they perceived as a disturbing trend in biological evolutionary theory-the "Panglossian" mindset that begets the adaptationist "just-so story." Similar caution has been urged regarding some of the recent attempts to apply "selectionist" models to archaeological problems (O'Brien and Holland 1992, 1995). More recently, Goodman (1994) has expanded this criticism to encompass biological anthropology - specifically paleonutrition and paleoepidemiology-noting that several recent publications in the field appear to have been based on a poor understanding of evolutionary theory that focuses on short-term "adaptations" while ignoring long-term, functional, physiological costs.

Interestingly enough, these wake-up calls have

rung at the same time that Williams and Nesse (1991) have called for the integration of traditional Darwinian mechanics into the healing arts under the rubric of "Darwinian Medicine." Slightly predating the work of Williams and Nesse, Kent (1986) and Stuart-Macadam (1988, 1989, 1990, 1991, 1992) employed an evolutionary paradigm in a reevaluation of the role of diet as a contributing factor to porotic hyperostosis and cribra orbitalia. In place of the more traditional dietary model, they have proposed a Darwinian explanation that involves human physiologic response to bacterial and pathogenic intestinal parasites. While compelling in its attempt to place cribra orbitalia and porotic hyperostosis under the umbrella of evolutionary theory, there is the potential that misapplication of this "parasite model"

Thomas D. Holland a U.S. Army Central Identification Laboratory, Hawaii, Hickam Air Force Base, HI 96853-5530

Michael J. O'Brien — Department of Anthropology, University of Missouri, Columbia, MO 65211 
will lead to misinterpretation of the archaeological record.

Admittedly, at least for the present, the dietary model remains the more widely held. The parasite model, on the other hand, with its "hard-science" edge and the increasing popularity of evolutionary explanations, offers the more seductive siren's song. Therein, as Goodman (1994) has addressed in some depth, lies the danger. We agree it is time to reevaluate our thinking about maize and health, as well as all the other factors in this complex evolutionary web we call the origin of agriculture, but we question the need to replace one overly simplified model with another. Let there be no misunderstanding: This is not a criticism of the concept of Darwinian Medicine or the basic evolutionary approach that underlies the parasite model. It is, however, a call for caution, lest Gould and Lewontin's criticisms strike home.

\section{Diet vs. Parasites in Theory}

For well over a century the pitted lesions of the cranial vault and orbital roof that characterize the paleopathological conditions of porotic hyperostosis (after Angel 1966) and cribra orbitalia have been noted in skeletal samples from around the world. While the two manifestations can occur independently, they generally are believed to arise from a common etiology. Proposed etiological agents have run the gamut from genes (Welcker 1888), to cultural practices (e.g., Wood-Jones 1910), to environmental hazards (Hrdlicka 1914). Presently, a consensus of the scientific community favors acquired iron-deficiency anemia as the causative agent. What can be called a "dietary model" for the disorder was first proposed by Williams (1929), and while supportive articles followed (e.g., Henschen 1961), it would take the work of El-Najjar and colleagues (El-Najjar 1976; El-Najjar and Robertson 1976; El-Najjar et al. $1975,1976,1982)$ to refine the argument into the "maize-dependency" model now so widely cited.

In its now-classic form, the maize-dependency model links porotic hyperostosis to diets containing staples that either are low in iron or that contain substances that interfere with iron absorption. Tannins (polyphenols), for example, found in vegetable sources such as millet and sorghum (as well as in tea and coffee) inhibit iron absorption (Morris 1990). Cereal staples, maize in particular, have been implicated because of their naturally low iron content and the chelating effect of phytic acid (which renders as nutritionally unusable any iron that is present). Compounding the problem are that (a) many staples, such as maize, lack the enzyme phytase to counteract the phytic acid and (b) iron from vegetable sources generally is absorbed poorly under the best of circumstances. In fact, only 1 to 7 percent of the iron in vegetable staples such as rice, maize, black beans, soybeans, and wheat is readily absorbed when consumed alone, i.e., without meat (Bothwell et al. 1979). Thus the dietary model posits that individuals dependent on a vegetable staple, such as maize, will suffer more iron-deficiency anemia, which in turn triggers more hyperblastic bone-marrow response, which in turn causes porotic hyperostosis. Refinements to the model now allow for more complexity in the equation (e.g., Hengen 1971; Lallo et al. 1977; Mensforth et al. 1978; Walker 1986), but reliance on iron-poor staples remains the prime mover.

In contrast, the parasite model, building on the work of Hengen (1971), posits that iron deficiency is in reality an adaptive response to environmental stress. The reasoning is that since laboratory studies have shown a link between iron and pathogen growth, then a state of chronic hypoferremia would make it "difficult for pathogens to obtain the necessary iron for growth and development" (Stuart-Macadam 1992:44) and would in turn be beneficial. This has the effect of standing the maize-dependency hypothesis on its head; porotic hyperostosis is viewed not so much as a sign of nutritional stress as it is a reflection of "attempts of [a] population to cope with and adapt to its environment" (Stuart-Macadam 1992:44; see also Kent and Weinberg 1989). Thus, hyperostosis is viewed as a sign of successful adaptation rather than as an indicator of maladaptation.

\section{Limitations of the Parasite Model}

The parasite model crafted by Stuart-Macadam (1992:40) seemingly is founded on two points:

1. Except in cases of outright malnutrition, diet plays a minor role, if any, in the development or iron deficiency anemia.

2. Mild iron deficiency, or hypoferremia, is not necessarily a negative condition; in fact, it is one of the body's defenses against disease. 
Our primary concern echoes that of Goodman (1994) and centers on the assertion that iron deficiency is a viable adaptation. We believe it is wrong to cite porotic hyperostosis as any sort of indicator of evolutionary success. In fairness, no one is arguing that porotic hyperostosis is adaptive, but what is being argued is that the condition, or state, that produces cribra orbitalia and porotic hyperostosis, i.e., hypoferremia, is adaptive. Porotic hyperostosis is not viewed in the traditional role of a nutritional-stress indicator, but rather is seen as an "indication that a population is attempting to adapt to the pathogen load in its environment" (Stuart-Macadam 1992:39). And therein lies the stumbling block. This is not simply semantic disagreement. We believe that anemia, whether it is caused by maize or nematodes, is a sign that something is seriously wrong. We are not alone in this view. Cook (1990:302) notes that "there is now considerable evidence that mild iron deficiency even without anemia is associated with significant health consequences and should be considered failed adaptation" (emphasis added). Goodman (1994:164) views this attempt to explain iron deficiency as an adaptation as "Cartesian Reductionism," i.e., the idea that "the human body can homeostatically adapt to insults and deprivations [while] all other systems are disconnected in Cartesian terms from the readjusting subsystems." This view ultimately leads to "a vulgarization of the concept of adaptation: signs of stress are seen as adaptations for no other reason than that they exist in stressed but surviving organisms."

The central idea of hypoferremia as adaptation is grounded in the work of Weinberg $(1974,1984)$, among others, who has shown a link between an organism's ability to sequester iron and immunity to certain bacterial forms. But, assuming that "mild iron deficiency may actually protect against infection under very specific laboratory conditions" (Dallman 1987:332) is not the same as demonstrating that hypoferremia has any adaptive value as a means of alleviating parasitic worm infestation. Furthermore, even if we accept that the "body's methods of withholding the iron needed by microorganisms for their multiplication constitute an important way of reducing the virulence of bacterial and protozoan infections," it does not mean that "iron deficiency is ever a desirable state" (Scrimshaw 1990:52).
First of all, nutritional forms of anemia are morbid, if not deadly. Iron deficiency, even without anemia, "leads to a suite of functional costs" (Goodman 1994:167) that includes reduced cellmediated immunity, physical- and intellectualgrowth disorders, and compromised work capacity (Baynes and Bothwell 1990; Beard 1990; Pollitt 1987; Scrimshaw 1990, 1991; Spurr 1990). Increased susceptibility to respiratory diseases, for example, has been linked to low iron levels (Scrimshaw 1991), and even Weinberg (1984:76) reports that if the host "become[s] markedly iron deficient from severe or prolonged iron starvation ... susceptibility to infection can be intensified rather than diminished." But perhaps more importantly, from a fitness perspective, iron deficiencies have their "greatest impact on perinatal morbidity and mortality"- -so much so that "a decrease in [maternal] hematocrit by even a single [percentage] point" is associated "with a $24 \%$ increase in the risk of prematurity" (Cook 1990:302). Thus, lapsing into hypoferremia (and certainly into anemia) at best can be considered a short-term solution to a long-term problem.

Second, given what we infer the hygienic conditions facing early agriculturists to have been, it is reasonable to assume that parasitic infestation was a chronic concern that would necessitate the maintenance of a life-long (at least reproductive life) hypoferremic state, with all the attendant health concerns, to defend against reinfection (though some immunity seems to develop as the result of exposure to worm antigens). In general, it can be assumed that unless the living environment is sanitized, treatment of the condition is uselessa fact that "has bedeviled public health workers since the days of the massive early control programs" (Kiple 1993:786).

So while hypoferremia may impart some benefit in the face of parasitic assaults, an immune system compromised by chronic anemia is not, by default, a viable evolutionary solution. From selection's viewpoint it makes little difference whether one dies from hookworms or from complications of anemia. Therefore, it is problematic to view porotic hyperostosis as a reflection of a population's attempt to "cope with and adapt to its environment" (Stuart-Macadam 1992:44), or to view individuals with porotic lesions as having been "more successful in adapting to their environment 
than individuals who did not live long enough to produce [a] bony response to a pathogen." This is true especially in light of Stuart-Macadam's (1985) assertion that cribrotic lesions seen in adult skulls are not so much a reflection of the true occurrence of the condition as they are the failure of the lesions to remodel in those individuals. (This underscores the need to simultaneously analyze evidence of pathogens and mortality.)

Obviously, there is an inherited mechanism in humans that conserves iron, and just as obviously such a mechanism has adaptive value under specific (and often tightly circumscribed) conditions. But it should also be obvious that "nutritional immunity," especially the relation between physiological iron levels and disease resistance, is far from clearly understood. Strauss (1978:662) notes that one reason iron-immunity studies are at variance with each other is that the nutritional status of the patient subjects often "is incompletely studied," and there may be the confounding influence of "intercurrent infections." This led Keusch (1990:87) to sum up the conflicting research with the observation that the only thing that emerges with any clarity is that "these data are overinterpreted."

Likewise, we suspect that the correlation between hypoferremia and parasitic infestation has been overinterpreted. Certainly, no one will deny that a correlation exists. This is a logical consequence, since (1) nutritional iron deficiency, i.e., hypoferremia or anemia, results "when the amount of iron that can be absorbed from the diet is insufficient to meet physiological requirements" (Bothwell et al. 1979:7), and (2) a single hookworm can remove between $.20 \mathrm{ml}$ and $.05 \mathrm{ml}$ of blood daily (Ancylostoma duodenale or Necator americanus, respectively), an amount that can lead to a negative iron balance when a large number of worms is involved (Cook 1980). Therefore, chronic blood loss equals anemia. But this correlation is meager data on which to argue that low iron levels are a response to, rather than the result of, an environmental insult. As Bothwell et al. (1979:61) point out, "since the hookworm load is small in the vast majority of individuals in endemic areas, the widespread prevalence of anaemia implies that other factors also contribute to the cause." Therefore, it is not surprising that iron deficiency anemia is more prevalent in tropical areas where intestinal parasitic infestation is common, and the intake of animal protein is low.

But assuming the parasite model has some validity, what is the logical conclusion to the proposition that cribra orbitalia is a hallmark of an adaptive state? If we assume that (1) late prehistoric agricultural women and children suffered from iron deficiency for the same reasons that their modern counterparts in the United States do, and (2) the parasite theory is correct, then we are placed in the ironic position of being forced to conclude that anemic women and children were among the healthiest members of their communities, since their hypoferremic state conferred upon them a mantle of protection from a variety of ubiquitous pathological insults. Similarly, iron-poor agricultural staples would be selected through time precisely because the staples were iron poor. In an evolutionary model for the origin of agriculture (sensu Rindos 1984), one could posit that maize, for example, became locked in a coevolutionary spiral in which humans nurtured low-iron, high-phytic-acid varieties to counter the insult from intestinal parasites, while increasingly ironpoor maize varieties flourished by enhancing the fitness of the human agents. (From a coevolutionary perspective, it is interesting to note that one of the earliest cultivated plants in prehistoric America-Chenopodium sp.- has been used by Western physicians and some aboriginal peoples as an anthelmintic to treat hookworm infection [e.g., Kiple 1993; Reinhard 1988]; although it is doubtful that this was much of a factor in its cultivation.) This line of reasoning is, of course, ridiculous, but goes to underscore the logical inconsistencies of the model and the inherent limitations of the just-so story.

Our second concern focuses on the devaluation of diet in the etiology of anemia. In some respects, this is perhaps the most far-reaching consequence of adopting the parasite model, i.e., by conflating nutrition with subsistence activities, the model has the potential to sever the well-documented link between agriculture and cribra orbitalia (see papers in Cohen and Armelagos 1984). As alluded to above, the idea that diet is not the lone agent in causing porotic hyperostosis certainly is not new. Almost 25 years ago, Hengen (1971:71) traced the etiology of porotic hyperostosis to "bad hygienic conditions, i.e., insufficient alimentary iron uptake and parasitic infestations, respectively" (emphasis 
added). Similarly, 10 years ago Goodman et al. (1984:31) acknowledged that "high frequencies of infectious disease, a diet low in iron or one that inhibits iron absorption, and cultural factors such as weanling diarrhea, all increase the potential for porotic hyperostosis." Similar examples abound (e.g., Lallo et al. 1977; Mensforth et al. 1978; Walker 1986), including a recent work by Kent and Dunn (1993). The problem is that, despite Stuart-Macadam's (1992:45) assertion that it is "incorrect to focus exclusively on any one factor in terms of an explanatory model," the parasite model, in effect, does just that. By dismissing diet (involving maize or any other iron-poor staple) as a significant factor in the etiology of the condition, it effectively decouples (though perhaps inadvertently) the link that does exist between porotic hyperostosis and agriculture as a subsistence strategy. It is more realistic, we believe, to adopt the position taken by Rose et al. (1984:418) that while "maize agriculture in itself is not deleterious to health," the "culture change and population nucleation [associated with it] are the prime stimuli for increased stress and morbidity." It is this "culture change" that interests archaeologists the most.

Stuart-Macadam's proposition that "except in cases of outright malnutrition, diet plays a minor role, if any, in the development of iron deficiency anemia" (Stuart-Macadam 1992:40) is patently tautological. Since malnutrition, which is defined as "an inadequate supply of nutrients to the cell" (Williams 1985:329), includes iron deficiency, an adequate diet (which must include sufficient iron) will of course play a minor role in the development of iron-deficiency anemia simply because it is adequate. Conversely, an inadequate diet, i.e., one that is iron deficient, will by definition play a role in the development of anemia. (Kent and Dunn [1993], however, present an example of a population with seemingly adequate iron intake but a low, average, circulating-iron level. This is explained by the sequestration of iron in the liver to render it unavailable to bacteria and parasites.) If this were just another problem with definitions, it could be dismissed easily. But more thorny than semantics is the fact that this proposition is propped up by modern clinical studies that focus on diet as a contributing factor in the development of iron-deficiency anemia. Stuart-Macadam (1992:41) cites a comment by Arthur and Isbister
(1987) that "even if iron intake was reduced to nil, which is virtually impossible even with the most frugal diets, it would still take at least two to three years to develop iron deficiency anemia, and probably even longer because losses would decline as levels declined" (emphasis added). Thus, the focus is on the development of the condition rather than on the maintenance of the condition. A closer reading of Arthur and Isbister (1987:173) reveals that they qualify the above statement by noting that "consequently iron deficiency is almost never due to dietary deficiency in an adult in our community" (emphasis added). The community under study was Sydney, Australia, comprising individuals maintaining an "average Western diet" (1987:173). Although it might be true that an individual with adequate iron stores would require two to three years of poor eating to develop anemia, what about those individuals who are chronically impaired? Individuals with already depleted iron stores might easily be maintained in an anemic state as the result of their diet. Arthur and Isbister (1987:176) acknowledge that while "nutritional deficiency as a sole cause [of iron deficiency] must be exceedingly rare ... this does not deny the fact that poor iron intake may facilitate the appearance of iron deficiency." We maintain that the use of nutritional models derived from clinical studies of modern Western populations are, at best, poor analogs for use on prehistoric agriculturists.

The inapplicability of modern clinical studies of dietary needs to archaeological populations does not mean, however, that all modern studies are inappropriate. We suspect that early prehistoric agriculturists were physiologically identical to modern populations, and, therefore, modern studies that focus on basic biology probably have greater applicability. With this in mind, we again acknowledge that the iron-withholding mechanism of the human body, past and present, is a remarkably adaptive feature (or "adjustment" sensu Dubos [1978]). But when Stuart-Macadam (1992:41) asserts that "a short-term reduction in absorption of dietary iron does not compromise iron metabolism because there is still ample iron available from the destruction of old red blood cells," we again are faced with the problem of attempting to place what probably was a chronic problem, i.e., early agriculturists' life-long dependence on iron-poor dietary staples, into the frame- 
work of "short-term reduction[s]" and "ample iron" stores characteristic of modern clinicalstudy populations. Underscoring this problem, Cook (1990:305) notes that because of the remarkable iron-conserving mechanisms of the body, it is "impossible to study the effect of dietary inhibitors on iron balance in iron-replete individuals although some groups still attempt to use this approach" (emphasis added). Similarly, while we may agree that "iron metabolism is almost a closed system, with as much as $90 \%$ of the iron required for the production of new red blood cells being obtained by the turnover of senescent red blood cells" (Stuart-Macadam 1992:41), we must not lose sight of the fact that the iron system only approximates a closed system. With a few exceptions-vitamin D (which is a derivative of cholesterol in the skin) and a few other vitamins such as $\mathrm{K}$ (which are synthesized by bacteria in the gut)-all nutrients, including iron, must be introduced into the human body. And while the human body can do a remarkable job of recycling certain minerals, such as iron, it cannot replace a mineral that was never obtained or has been lost.

Obviously, significant iron losses are a routine part of life. For example, adult males lose an average of $.9-1.0 \mathrm{mg} /$ day: $.6 \mathrm{mg}$ in feces, $.2-.3 \mathrm{mg}$ by exfoliated skin, and $<.1 \mathrm{mg}$ in urine (Bothwell et al. 1979; Green et al. 1968). Small, though seemingly insignificant, amounts may even be lost through perspiration and bile (Bothwell et al. 1979; Brune et al. 1986). The iron requirements of menstruating women-.5 mg/day over that of adult men (National Academy of Sciences 1980) - is further evidence of the nutritional consequences of blood loss. Women lose approximately $15 \mathrm{mg}$ of iron from their almost "closed system" with each menstrual period. Similarly, a woman's daily iron requirements increase by approximately $3.5 \mathrm{mg}$ during pregnancy (American Medical Association 1968). If the diet is not supplemented at these times, a negative iron balance will develop. Multiple or frequent pregnancies only serve to compound the problem. Arthur and Isbister (1987:182) note that even "if a female can achieve positive iron balance of 1 to 2 $\mathrm{mg}$ /day postpartum it will still take months or years to replenish stores." What was the situation facing early prehistoric agriculturists? Just how iron replete were they? Many children and adoles- cents, prehistoric or modern, regardless of their cultures' subsistence practices, face problems in obtaining the iron needed for tissue growth and red blood cell production. Fetal iron stores are sufficient for only four to six months after birth, and breast milk is notoriously iron poor-declining from $.5 \mathrm{mg} /$ liter during the first month postpartum to $.3 \mathrm{mg} /$ liter by month four (Johnson 1990). Children breast-fed for longer periods, without some iron supplement, fall even deeper into iron deficit, and if a child is then weaned on an ironpoor cereal gruel (such as maize or many of the other cereal staples so commonly associated with early agriculture), the problem is compounded. In many cultures, weanling diarrhea further acerbates the problem (Gordon et al. 1963). Thus, unlike the well-nourished modern community of adults in Arthur and Isbister's study, and similar clinical environments, the situation facing early agriculturists probably was not one of individuals with adequate nutrient stores who were subjected to short-term nutritional assaults, but rather the problem may have been one of individuals who were in a chronic state of iron deprivation from birth.

How would many early agriculturists, such as those of the prehistoric American Midwest, achieve positive iron balance? Certainly not with an iron-poor staple such as maize. The National Academy of Sciences $(1980: 138)$ concedes that "the increased requirement [of iron] during pregnancy cannot be met by the iron content of habitual diets in the United States, nor by the existing iron stores of many women; therefore, daily supplements of iron are recommended." Similarly, Fairbanks (1994:202) notes that "the amount of iron contained in red meats or liver is simply not enough" to prevent iron deficiency in pregnant females, and Baynes and Bothwell (1990:137) point out that the iron requirement of a women in her second and third trimester "cannot be met by any diet." In fact, the recommended supplement for pregnant females is $30-60 \mathrm{mg} / \mathrm{day}$, i.e., two to three times the recommended dietary allowance for nonpregnant, well-nourished females.

Obviously, this is a complex issue, and we believe, as do Hill and Armelagos (1990:60), that "the cause-effect relationship may not be as obvious as one might expect," as "systemic elements do not exist independently of one another." Our common-sensical reassertion that diet must con- 
tinue to be viewed as a significant contributing factor to anemia does not mean that disease and parasitic infestations are not factors. We know of no researcher who does not accept the fact that blood (and therefore, iron) lost through a wide range of causes-parasites, injury, metabolic disorders, infections, ceremonial bloodletting, pregnancy-are prime factors in acquired anemia. Conversely, we do not believe that to acknowledge the importance of any of these other factors we must, as the parasite model would seem to suggest, diminish the importance of diet.

Equally unambiguous is the fact that the pattern of porotic hyperostosis and cribra orbitalia seen worldwide is not accidental. Children and adolescents overwhelmingly are affected (e.g., El-Najjar et al. 1976; Lallo et al. 1977; Mensforth et al. 1978). Stuart-Macadam (1985) asserts that the characteristic cribrotic lesions of the condition are formed during childhood and remain visible in later life only as the result of a failure of the bone to remodel completely. Some researchers (e.g., Carlson et al. 1974) also maintain that females often are affected preferentially (see StuartMacadam [1982] for the opposing view). Why children? Why females? Are they significantly more susceptible to parasitic infestation? Female cases possibly are an artifact of impaired remodeling (relative to males) caused by ongoing demands of reproductive physiology. But interestingly enough, these classes also correspond with the four most-common cohorts in the United States in which iron intake is insufficient: (1) infancy, because of the low iron content of milk; (2) childhood and adolescence, when growth demands outstrips nutrient stores; (3) the female reproductive period, because of the loss of blood through menstruation; and (4) pregnancy and childbirth, because of the demands of the developing fetus (Dallman et al. 1984; National Academy of Sciences 1980). Even in the relatively well-nourished United States, 35-58 percent of "young, healthy women have been found to have some degree of iron deficiency" (Fairbanks 1994:196), and almost 6 percent of girls between 15 and 17 years of age are clinically anemic (Baynes and Bothwell 1990). For women and children in tropical regions (with a high incidence of helminthiasis, poor nutrition, prolonged breast-feeding, and numerous pregnancies), iron deficiency "is a prevalent disorder with adverse consequences" (Fairbanks 1994:197). The majority of women (presumably in any culture) who do not take iron supplements during pregnancy will deplete their iron stores (Cook 1990:302).

In contrast, Stuart-Macadam notes several exceptions to the seeming correlation between agricultural subsistence and porotic hyperostosis. These exceptions to the rule would be compelling if proponents of the maize-dependency model argued that this was a clear-cut unifactorial issue, i.e., that maize, and nothing but maize, is involved in the development of anemia. However, few dietary proponents would offer up such a simplistic explanation. The fact that a highland Ecuador agricultural group shows little evidence of porotic hyperostosis, while a California iron-rich maritime group exhibits a high frequency of cranial lesions (to use the same examples as Stuart-Macadam [1992]), might owe its explanation as much to a multitude of variables that are undocumented or underappreciated, as it does to the complexity of iron metabolism or to the parasitic lifestyle of nematode worms. For example, Walker's (1986) explanation for the distribution of porotic hyperostosis among California Channel Island groups is illuminating. In his study, the coastal populations subsist on diets with sufficient iron. The conclusion that Stuart-Macadam draws from this pattern is that since the diet contains adequate iron, then diet cannot be a significant etiological agent. But Walker (1986) linked the occurrence of cribra orbitalia among these groups to a suite of factors, including diarrheal infections (from contaminated water), prolonged breast-feeding, helminth infection (from eating raw fish and sea mammal meat), and seasonal protein-calorie malnutrition. Note that three of these four factors involve either (1) limited nutrient intake (prolonged breast-feeding and protein-calorie malnutrition) or (2) impaired nutrient absorption and retention (including diarrheal infections). The fourth variable-helminth infection-involves nutrient loss that must in turn be balanced by nutrient intake. So even among groups with iron-rich subsistence bases, diet still plays an important role in the development of porotic hyperostosis. The real problem is that "variables exist in statistically confounding relationships [and] interactions in which they perpetuate, reinforce, or even cancel the effects of each 
other within the system" (Hill and Armelagos 1991:60). If we are honest, we must admit to being woefully uninformed about the true breadth and detail of prehistoric subsistence, and until we more adequately flesh out our knowledge base, we will not be in a position to adequately discern what factors are preeminent in the development of anemia in specific prehistoric populations.

Further compounding the issue may be the inherent problem encountered whenever one employs disparate archaeological data. In other words, different researchers, with dissimilar levels of training and operating under various paradigmatic umbrellas, do not always produce comparable results (although Buikstra and Ubelaker's [1995] attempts to standardize bioarchaeological analysis may help alleviate this problem in the future). We do not have a good understanding of the magnitude of intra- or interobserver error made in documenting cribra orbitalia and porotic hyperostosis in skeletal assemblages; even when data are derived by a single researcher, the results often are amenable to several interpretations. For example, Stuart-Macadam (1992) cites Hengen's (1971) examination of over 5,000 skulls from a variety of cultural contexts that appeared to demonstrate that the incidence of porotic hyperostosis was directly correlated with proximity to the equator. Stuart-Macadam (1992) also notes that several other researchers (e.g., Hrdlicka 1914; ElNajjar 1976) have observed the relatively high frequency of porotic hyperostosis at lowland and coastal sites vs. its relative rarity in highland contexts. She (1992) then employs these patterns to implicate parasites as the ultimate cause of porotic hyperostosis, since the patterns mirror somewhat the favored environments of many pathogenic microorganisms. A counter (and more traditional) explanation, however, might be that this distribution correlates positively with locations of the primary centers of agriculture. For example, the "hookworm belt" (first delineated in 1910) girdles the earth between $30^{\circ} \mathrm{S}$ and $36^{\circ} \mathrm{N}$ latitude (Kiple 1993) and closely approximates the primary distribution of maize. Hookworm larvae even prefer the same light-sand and loamy soils (Kiple 1993) so commonly associated with prime maize-growing croplands. Thus the geographic distribution of cribra orbitalia overlaps with several variables.

The point we wish to make is that it is unrea- sonable to dismiss diet-especially those low in iron-as a factor in acquired anemia. Even in anemia that demonstrably is brought on by parasitic infections such as ancylostomiasis (hookworm disease), the severity of the condition is the product of (at least) three interconnected factors: (1) the iron content of the host's diet, (2) the host's stored iron reserves, and (3) the intensity and duration of the infection (Cook 1980). The correlation that exists between porotic hyperostosis and early agriculturists is neither a statistical anomaly nor a coincidence. Certainly the degradation of hygiene that accompanied the population growth and increase in sedentism associated with early agricultural communities created situations ripe for pathogenic infestation (cf. Kent and Dunn 1993), but earlier pre-agricultural hunter-gatherer groups (which appear to have a relatively lower incidence of porotic hyperostosis) were not immune from blood loss or parasites - and certainly not from childbirth. In another study cited by StuartMacadam (1992), Dunn (1972) found that the hunting, gathering, and fishing Negritos of the Malayan rain forest had the greatest number of intestinal parasite species of any ethnic group in the study. It is reasonable to assume that Malayan Negritos are not the only hunter-gatherer group to suffer from intestinal worms. Reinhard (1990) points out that the earliest recorded presence of intestinal parasites in North America-human pinworm (Enterobius vermicularis) - dates to ca. 8000 B.C. at Danger Cave, Utah. (See Reinhard [1988, 1990] for evidence of a relatively lower helminth load in some hunter-gatherer groups of the Colorado Plateau and American Southwest.) Currently some one billion people, approximately one-quarter of the world's population, have hookworm (A. duodenale or $N$. americanus) infections, and hundreds of millions suffer from roundworms (Ascaris lumbricoides) (Cook 1980). Therefore, if hunter-gatherer groups also lose blood and acquire parasites, why then do bioarchaeologists report that the skulls of earlier hunter-gatherer groups typically do not exhibit the evidence of anemia that the later agriculturist groups do? We suspect that when all other variables are held constant, gross iron intake may tip the scale. Thus, any model attempting to explain the occurrence, frequency, and distribution of cribra orbitalia and porotic hyperostosis must include diet. 


\section{Conclusions}

For health-care workers, the relation between iron supplementation and resistance to disease is a policy matter of grave, ethical concern. Fortunately for most anthropologists, the topic is more of an academic one-something akin to how many hookworms can dance on the head of a pin. Ultimately, the distinction between the effects of diet and the human physiologic response to intestinal parasites would be of little concern to most archaeologists were it not for the fact that we are such shameless - at times alarmingly uncriticalborrowers. Like scientific magpies, we seem irresistibly drawn to any bright, shiny theory. Kent and Stuart-Macadam clearly understand and appreciate the complex nature of iron metabolism, but most of us do not. This paper is not a rejection of the role of parasites in the explanation of cribra orbitalia and porotic hyperostosis. StuartMacadam (1992:45) concedes that "the etiology of porotic hyperostosis is not simplistic but can best be understood in terms of synergistic interactions." We agree.

We believe, as do Bothwell et al. (1979:23), that "[the] geographic variation, and the variation ascribable to ethnic and economic factors, are mainly the result of dietary differences, although increased iron losses due to hookworm infestation may also play a part." We also agree with Hill and Armelagos (1991:60) that "future studies [of cribra orbitalia] should not be too quick to confuse cause of anemia with correlation to environmental factors" (emphasis original; see also Walker [1986:353]). The real focus of interest for most archaeologists is not what causes cribra orbitalia or porotic hyperostosis (not that it would hurt us to have a better understanding of the causes), but rather, what do these occurrences signify? What are the attendant conditions under which porotic hyperostosis and cribra orbitalia occur? In fact, what most archaeologists really are interested in is how these particular skeletal lesions correlate with changes in subsistence strategy. For all the compelling insight of the parasite model, it is crucial that it not cause us to lose sight of the linkage between pitted skulls and the effects of agriculture.

It is of passing interest that even nonnutritional sickle-cell anemia appears to be indirectly correlated to subsistence practices. Durham
(1991:146), in his coevolutionary model, concluded that a "finding of importance for our purposes is the evidence that culture, specifically the know-how of slash-and-burn agriculture, has played an instrumental role in the genetic evolution of West African populations" with regard to inherited anemia. If nonnutritional forms of anemia correlate with subsistence activities (albeit through the intermediate vector of malaria-bearing mosquitoes), it is even more unreasonable to sever nutritional anemia from its subsistence base.

Stuart-Macadam (1992:42) poses the question, "If diet is not the major etiological factor in porotic hyperostosis, then what is?" We suspect that the answer may well be that nothing is the major factor; rather, there may be (and most likely is) a multitude of more-or-less equally important, and interdependent, factors. It is this interdependency that all too often falls victim to the seductive lure of a simple just-so model. The danger, Goodman (1994:171) cautions, lies in viewing human physiology as if it were "no more complex than house plumbing." The etiology of porotic hyperostosis no doubt is as complicated as our explanations are simple. Humans are complex creatures involved in an even more complex evolutionary web, and it is essential that in our explanatory, Panglossian zeal that we not construct straw men. The intricacies of human physiologic response to intestinal parasites is a fascinating niche that the mechanics of Darwinian theory have yet to exploit fully. The eventual clarification of the role played by parasites in the selective fitness of early humans will be a welcome addition to our understanding of the past. The evolutionary model is a broad one with room for many variables.

Acknowledgments. This paper benefited greatly from the suggestions of Mary Lucas Powell, as well as from Kristin Sobolik and several anonymous reviewers. We are particularly grateful for their bringing Alan Goodman's article to our attention. Early drafts of this paper were read by Bruce Anderson, William Grant, Richard Harrington, Lisa Hoshower, and Robert Mann; we appreciate their comments and insights. Sheridan Wigginton translated the abstract.

\section{References Cited}

American Medical Association (Committee on Iron Deficiency)

1968 Iron Deficiency in the United States. Journal of the American Medical Association 203:407-412. 
Angel, J. L.

1966 Porotic Hyperostosis, Anemias, Malarias and the Marshes in Prehistoric Eastern Mediterranean. Science 153:760-762.

Arthur, C. K., and J. P. Isbister

1987 Iron Deficiency: Misunderstood, Misdiagnosed and Mistreated. Drugs 33:171-182.

Baynes, R. D., and T. H. Bothwell

1990 Iron Deficiency. Annual Review of Nutrition $10: 133-148$

Beard, J.

1990 Iron Deficiency, Thyroid Function, and Thermoregulation. In Functional Significance of Iron Deficiency, edited by C. O. Enwonwu, pp. 71-80. Meharry Medical College, Nashville.

Bothwell, T. H., R. W. Charlton. J. D. Cook, and C. A. Finch 1979 Iron Metabolism in Man. Blackwell Scientific Publications, Oxford.

Brune, M., B. Magnusson, H. Persson, and L. Hallberg 1986 Iron Losses in Sweat. American Journal of Clinical Nutrition 43:438-443.

Buikstra, J. E., and D. H. Ubelaker 1994 Standards for Data Collection from Human Skeletal Remains. Arkansas Archeological Survey, Fayetteville.

Carlson, D., G. Armelagos, and D. Van Gerven 1974 Factors Influencing the Etiology of Cribra Orbitalia in Prehistoric Nubia. Journal of Human Evolution 3:405-410.

Cohen, M. N., and G. J. Armelagos (editors)

1984 Paleopathology at the Origins of Agriculture. Academic Press, New York.

Cook, G. C.

1980 Tropical Gastroenterology. Oxford University Press, New York.

Cook, J. D.

1990 Adaptation in Iron Metabolism. American Journal of Clinical Nutrition 51:301-308.

Dallman, P. R.

1987 Iron Deficiency and the Immune Response. American Journal of Clinical Nutrition 46:329-334.

Dallman, P., R. Yip, and C. Johnson

1984 Prevalence and Cause of Anemia in the United States. American Journal of Clinical Nutrition 39:437-445.

Dubos, R.

1978 Health and Creative Adaptation. Human Nature (January):74-82.

Dunn, F. L.

1972 Intestinal Parasitism in Malayan Aborigines (Orang Asli). Bulletin of the World Health Organization 46:99-113.

Durham, W. H.

1991 Coevolution. Stanford University Press, Palo Alto, California.

El-Najjar, M. Y.

1976 Maize, Malaria and the Anemias in the PreColombian New World. Yearbook of Physical Anthropology 20:329-337.

El-Najjar, M. Y., J. Andrews, J. G. Moore, and D. G. Bragg 1982 Iron Deficiency Anemia in Two Prehistoric American Indian Skeletons: A Dietary Hypothesis. Plains Anthropologist 44:447-48.

El-Najjar, M. Y., B. Lozoff, and D. J. Ryan

1975 The Paleoepidemiology of Porotic Hyperostosis in the American Southwest: Radiological and Ecological Considerations. American Journal of Roentgenology and Radiation Therapy 25:918-924.

El-Najjar, M. Y., D. J. Ryan, C. G. Turner II, and B. Lozoff 1976 The Etiology of Porotic Hyperostosis Among the
Prehistoric and Historic Anasazi Indians of the Southwestern U.S. American Journal of Physical Anthropology 44:447-488.

El-Najjar, M. Y., and J. R. Robertson

1976 Spongy Bones in Prehistoric America. Science 193:141-143.

Fairbanks, V. F.

1994 Iron in Medicine and Nutrition. In Modern Nutrition in Health and Disease, vol. 1, edited by M. E. Shils, J. A. Olson, and M. Shike, pp. 185-213. Lea and Febiger, Philadelphia.

Goodman, A. H.

1994 Cartesian Reductionism and Vulgar Adaptationism: Issues in the Interpretation of Nutritional Status in Prehistory. In Paleonutrition, the Diet and Health of Prehistoric Americans, edited by K. D. Sobolik, pp. 163-177. Occasional Paper No. 22. Center for Archaeological Investigations, Southern Illinois University, Carbondale.

Goodman, A. H., D. L. Martin, and G. J. Armelagos

1984 Indications of Stress from Bone and Teeth. In Paleopathology at the Origins of Agriculture, edited by M. N. Cohen and G. J. Armelagos, pp. 13-49. Academic Press, New York.

Gordon, J. E., J. D. Chitkara, and J. B. Wyon

1963 Weanling Diarrhea. American Journal of the Medical Sciences 245:345-375.

Gould, S. J., and R. Lewontin

1979 The Spandrels of San Marco and the Panglossian Paradigm: A Critique of the Adaptationist Programme. Proceedings of the Royal Society of London B205:581-598.

Green, R., R. W. Charlton, H. Seftel, T. H. Brothwell, F. Mayet, E. B. Adams, C. A. Finch, and M. Layrisse

1968 Body Iron Execretion in Man: A Collaborative Study. American Journal of Medicine 45:336-353.

Hengen, O. P.

1971 Cribra Orbitalia: Pathogenesis and Probable Etiology. Homo 22:57-75.

Henschen, $\mathrm{P}$

1961 Cribra Cranii-A Skull Condition Said to Be of Racial or Geographical Nature. Pathologie et Microbiologie 24:724-729.

Hill, M. C., and G. J. Armelagos

1991 Porotic Hyperostosis in Past and Present Perspective. In A Life in Science: Papers in Honor of J. Lawrence Angel, edited by J. E. Buikstra, pp. 52-63. Scientific Papers No. 6. Center for American Archeology, Kampsville, Illinois.

Hrdlicka, A.

1914 Anthropological Work in Peru in 1913, with Notes on Pathology of Ancient Peruvians. Smithsonian Miscellaneous Collections 61:1-69.

Johnson, A. A.

1990 Iron Deficiency: Pediatric Epidemiology. In Functional Significance of Iron Deficiency, edited by C. O. Enwonwu, pp. 57-66. Meharry Medical College, Nashville.

Kent, S.

1986 The Influence of Sedentism and Aggregation on Porotic Hyperostosis and Anaemia: A Case Study. Man 21:605-636.

Kent, S., and E. Weinberg

1989 Hypoferremia: Adaptation to Disease? New England Journal of Medicine 320:672.

Kent, S., and D. Dunn

1993 Etiology of Hypoferremia in a Recently Sedentary 
Kalahari Village. American Journal of Tropical Medicine and Hygiene 48:554-567.

Keusch, G. T.

1990 Immunity and Infection in Iron Deficiency. In Functional Significance in Iron Deficiency, edited by C.

O. Enwonwu, pp. 81-91. Meharry Medical College, Nashville.

Kiple, K. F. (editor)

1993 The Cambridge World History of Human Disease. Cambridge University Press, Cambridge.

Lallo, J., G. J. Armelagos, and R. P. Mensforth

1977 The Role of Diet, Disease and Physiology in the Origin of Porotic Hyperostosis. Human Biology 49:471-483.

Mensforth, R., C. O. Lovejoy, H. Lallo, and G. J. Armelagos

1978 The Role of Constitutional Factors, Diet and Infectious Disease in the Etiology of Porotic Hyperostosis and Periosteal Reactions in Prehistoric Infants and Children. Medical Anthropology 2:1-59.

Morris, E. R.

1990 Dietary Factors Influencing Bioavailability of Dietary Iron. In Functional Significance in Iron Deficiency, edited by C. O. Enwonwu, pp. 33-44. Meharry Medical College, Nashville.

National Academy of Sciences (Committee on Dietary Allowances, Food and Nutrition Board).

1980 Recommended Dietary Allowances. 9th ed. National Academy of Sciences, Washington, D.C.

O'Brien, M. J., and T. D. Holland

1992 The Role of Adaption in Archaeological Explanation. American Antiquity 57:36-59.

1995 The Nature and Premise of a Selection-Based Archaeology. In Evolutionary Archaeology, edited by P. A. Teltser, pp. 175-200. University of Arizona Press, Tucson.

Pollitt, E.

1987 Effects of Iron Deficiency on Mental Development: Methodological Considerations and Substantive Findings. In Nutritional Anthropology, edited by F. Johnston, pp. 225-254. Alan R. Liss, New York.

Reinhard, K. J.

1988 Cultural Ecology of Prehistoric Parasitism on the Colorado Plateau as Evidenced by Coprology. American Journal of Physical Anthropology 77:355-366.

1990 Archaeoparasitology in North America. American Journal of Physical Anthropology 82:145-163.

Rindos, D.

1984 The Origins of Agriculture: An Evolutionary Perspective. Academic Press, New York.

Rose, J. C., B. A. Burnett, M. W. Blaeuer, and M. S. Nassaney

1984 Paleopathology and the Origins of Maize Agriculture in the Lower Mississippi Valley and Caddoan Culture Areas. In Paleopathology at the Origins of Agriculture, edited by M. N. Cohen and G. J. Armelagos, pp. 393-424. Academic Press, New York.

Scrimshaw, N. S.

1990 Functional Significance in Iron Deficiency. In Functional Significance in Iron Deficiency, edited by C. O. Enwonwu, pp. 1-13. Meharry Medical College, Nashville.

1991 Iron Deficiency. Scientific American (October):46-52. Spurr, G. B.

1990 Malnutrition, Work Performance and the Role of Iron. In Functional Significance of Iron Deficiency, edited by
C. O. Enwonwu, pp. 103-116. Meharry Medical College, Nashville.

Strauss, R.

1978 Iron Deficiency, Infections, and Immune Function: A Reassessment. American Journal of Clinical Nutrition 31:660-666.

Stuart-Macadam, P. L.

1982 A Correlative Study of Paleopathology of the Skull. Unpublished Ph.D. dissertation, Department of Physical Anthropology, Cambridge University, Cambridge.

1985 Porotic Hyperostosis: Representative of a Childhood Condition. American Journal of Physical Anthropology 66:391-398.

1988 Nutrition and Anaemia in Past Human Populations. In Diet and Subsistence: Current Archaeological Perspectives, edited by B. Y. Kennedy and G. M. LeMoine, pp. 284-287. University of Calgary, Calgary, Alberta.

1989 Nutritional Deficiency Diseases: A Survey of Scurvy, Rickets, and Iron-Deficiency Anemia. In Reconstruction of Life from the Skeleton, edited by M. Y. Iscan and K. A. R. Kennedy, pp. 201-222. Alan R. Liss, New York.

1990 Anemia in Past Human Populations. In Diet, Demography, and Disease: Changing Perspectives on Anemia, edited by P. Stuart-Macadam and S. Kent, pp. 151-170. Aldine de Gruyter Press, Hawthorne, New York.

1991 Porotic Hyperostosis: Changing Interpretations. In Human Paleopathology, edited by D. J. Ortner and A. C. Aufderheide, pp. 36-39. Smithsonian Institution Press, Washington, D.C.

1992 Porotic Hyperostosis: A New Perspective. American Journal of Physical Anthropology 87:39-47.

Walker, P. L.

1986 Porotic Hyperostosis in a Marine-Dependent California Indian Population. American Journal of Physical Anthropology 69: 345-354.

Weinberg, E. D.

1974 Iron and Susceptibility to Infectious Disease. Science 184:952-956.

1984 Iron Withholding: A Defense against Infection and Neoplasia. Physiology Review 64:65-102.

Welcker, $\mathrm{H}$.

1888 Cribra Orbitalia, ein Ethologisch-Diagnostishes Merkmal am Shadel Mehrerer Menschrassen. Archaeological Anthropology 17:1.

Williams, G. C., and R. M. Nesse

1991 The Dawn of Darwinian Medicine. The Quarterly Review of Biology 66:1-22.

Williams, $\mathrm{H}$

1929 Human Paleopathology. Archaeological Anthropology 7:839-902.

Williams, S. R.

1985 Nutrition and Diet Therapy. Times Mirror/Mosby, St. Louis, Missouri.

Wood-Jones, F.

1910 General Pathology (including Diseases of the Teeth). In Report on the Human Remains, The Archaeological Survey of Nubia, Report for 1907-1908, vol. 2., edited by G. E. Smith and F. Wood-Jones, pp. 263-292. National Printing Department, Cairo, Egypt.

Received July 3, 1995; accepted September 25, 1996; revised November 7, 1996. 